\title{
Comparative analysis of some bioactive compounds in leaves of different Aloe species
}

\author{
Bunea Andrea ${ }^{1}$, Rugină Dumitrița $2^{*} \mathbb{D}$, Copaciu Florina ${ }^{1}$, Dulf Francisc ${ }^{3}$, Veres Anastasia', Sonia Socaci ${ }^{4}$ \\ and Pintea Adela ${ }^{2}$
}

\begin{abstract}
Although a vast number of Aloe species are known, only the Aloe vera and Aloe arborescens species are currently used by cosmetic and pharmaceutical industries. Therefore, the current study aims to complete the existent literature data with new information on the phytochemical composition of some lesser-known Aloe species, with the main focus on carotenoids and fatty acids. Among the analyzed species, Aloe aculeata and Aloe ferox had the highest content in carotenoids, the major pigments being lutein and $\beta$-carotene (according to HPLC analysis). The fatty acid profile of each Aloe species was analysed by GC-MS. Linolenic and linoleic acids were the major polyunsaturated fatty acids found in higher percent in Aloe ferox, Aloe spectabilis and Aloe marlothii. Instead, Aloe aculeata proved to have a distinct fatty acid profile, rich in monounsaturated fatty acids. Species such as Aloe arborescens and Aloe marlothii proved to have the highest antioxidant potential according to data of DPPH, ORAC, HPS assays, even if the richest one in vitamin $C$ was found to be Aloe spectabilis. Though the scientific research is mainly focused on the common species Aloe barbadensis, the current data suggests that other Aloe species could receive more attention from industry part, being great sources of bioactive compounds.
\end{abstract}

Keywords: Aloe sp., Antioxidant activity, Ascorbic acid, Carotenoids, Fatty acids, HPLC, GC-MS

\section{Introduction}

The genus Aloe (Family: Xanthorrhoeaceae) comprises over 500 species, of all the most well-known being Aloe vera. Aloe species, besides their widespread use as a food ingredient, have been intensely exploited in the traditional medicine of other cultures for their curative and therapeutic properties [1,2].

The biological properties of Aloe such as anti-inflammatory, antimicrobial, anti-tumoral, and antioxidant, as well as wound healing ones are sustained by numerous in vitro and in vivo studies $[1,3]$. These properties could be attributed to various compounds of the phytochemical profile of Aloe extracts, rather than to one single class

\footnotetext{
*Correspondence: dumitrita.rugina@usamvcluj.ro

${ }^{2}$ Faculty of Veterinary Medicine, University of Agricultural Sciences and Veterinary Medicine, Calea Manastur, No. 3-5, 400372 Cluj-Napoca, Romania

Full list of author information is available at the end of the article
}

of compounds. Focusing on the phytochemical content of leaves, in Aloe vera valuable molecules such as fatty acids (palmitoleic acid, linoleic acid), phenolic acids (phenol, vanillic, homovanillic, protocatechuic) and sterols (cholestanol) were found [4]. In a recent study, the phytochemical profile of the leaf exudates reported that many Aloe species contain free and glycosylated chromones, aloin and hydroxyaloins. Among the examined species in the same study, A. marlothii, and A. melanacantha were found to be the richest ones in total polyphenols, flavonoids and flavonols [1].

Fatty acids are bioactive compounds and an important part of the phytochemical content of Aloe, being widely used as feedstocks in the food industry and in the manufacture of soaps, detergents and cosmetics [23]. Nevertheless, both saturated and unsaturated fatty acids are relevant for their biological functions [24]. Polyunsaturated fatty acids (PUFAs), especially omega-3 and omega-6 fatty acids, are important dietary fats having

(c) The Author(s) 2020. This article is licensed under a Creative Commons Attribution 4.0 International License, which permits use, sharing, adaptation, distribution and reproduction in any medium or format, as long as you give appropriate credit to the original author(s) and the source, provide a link to the Creative Commons licence, and indicate if changes were made. The images or other third party material in this article are included in the article's Creative Commons licence, unless indicated otherwise in a credit line to the material. If material is not included in the article's Creative Commons licence and your intended use is not permitted by statutory regulation or exceeds the permitted use, you will need to obtain permission directly from the copyright holder. To view a copy of this licence, visit http://creativeco mmons.org/licenses/by/4.0/. The Creative Commons Public Domain Dedication waiver (http://creativecommons.org/publicdomain/ zero/1.0/) applies to the data made available in this article, unless otherwise stated in a credit line to the data. 
numerous health benefits in humans. A right balance of these fatty acids in the human diet is crucial to prevent chronic diseases such as diabetes, obesity, cancer, and cardiovascular disease [25].

Carotenoids are molecules that exists in Aloe leaves, being components of the photosynthetic apparatus. They are known for their photoprotective and antioxidant properties. They play important roles for human health: as pro-vitamin A molecules (e.g. $\beta$-carotene), in eye protection (lutein and zeaxanthin), as antioxidants (lycopene, astaxanthin), for improvement of the cardiovascular health or cognitive functions [5].

Vitamin C (ascorbic acid) is a powerful dietary antioxidant, a water-soluble vitamin known to be essential to prevent scurvy or having positive effects in cardiovascular diseases [6] or diabetes [7]. It is also proved that it is able to improve the poor iron status and increase the absorption of iron [8]. Food and Drug Administration, FDA recommended that the amount of vitamin $C$ for human consumption to be $75 \mathrm{mg}$ per day for women and $90 \mathrm{mg}$ for men. Phytochemicals in the Aloes may protect ascorbate from degradation in vivo [9]. From all known 500 species, Aloe barbadensis also known as A. vera, respective $A$. arborescens and $A$. ferox have the highest commercial importance [10]. The best-known and the most studied one $A$. barbadensis proved also its clinical effectiveness [11]. A. arborescens and A. ferox properties and their potential use as skin-conditioning agents or food additives were proved and accurately revised in few previously published papers [12-15]. Apart from these three Aloe species, little research has been conducted on the commercial potential of the other ones, although many of them are endemic in southern Africa and constitute an important component of the local flora from ethnobotanical, ecological, and social perspectives $[2,16]$.
Only A. marlothii is used in ethnoveterinary medicine for wound healing and reduction of infection and pain [17].

The phytochemical composition of different parts of Aloe might vary due to climate change [18], water stress, growth period and seasonality [19, 20], light intensity [21] as well as processing techniques, such as drying procedures [22].

Regarding the phytochemical content of Aloe, the existent literature data is mostly focused on leaf gel $[13,23]$ and fewer on flower extracts [24]. However, as far as we know little work has been done on total leaf extracts. In this context, our study came to improve the existing knowledge on the phytochemical content of seven Aloe species. Therefore, we report here data about the carotenoids, fatty acids and vitamin $\mathrm{C}$ contents in whole leaf extracts of $A$. aculeata, $A$. africana, A. arborescens, $A$. barbadensis, A. ferox, $A$. marlothii, and $A$. spectabilis, as well as and their potential antioxidant activity (Fig. 1). To the best of our knowledge, this is the first study which offers a comprehensive overview about the carotenoids and fatty acids profile of some little investigated Aloe species, and certainly their individual phytochemical profile could be useful in varied industries.

\section{Materials and methods \\ Chemicals}

Methanol, ethyl acetate, petroleum ether, diethyl ether, tert-butyl methyl ether (TBME), sodium chloride, anhydrous sodium sulphate and chloroform, all were purchased from Merck (Darmstadt, DE). Lutein, zeaxanthin and $\beta$-carotene standards were provided by LGC Standards GmbH (Wesel, DE). 2,2'-Azobis(2-amidinopropane) dihydrochloride (AAPH), and 2,2-diphenyl-1-picrylhydrazyl (DPPH), 6-hydroxy-2,5,7,8-tetramethylchroman2-carboxylic acid (Trolox) and the chemicals used for

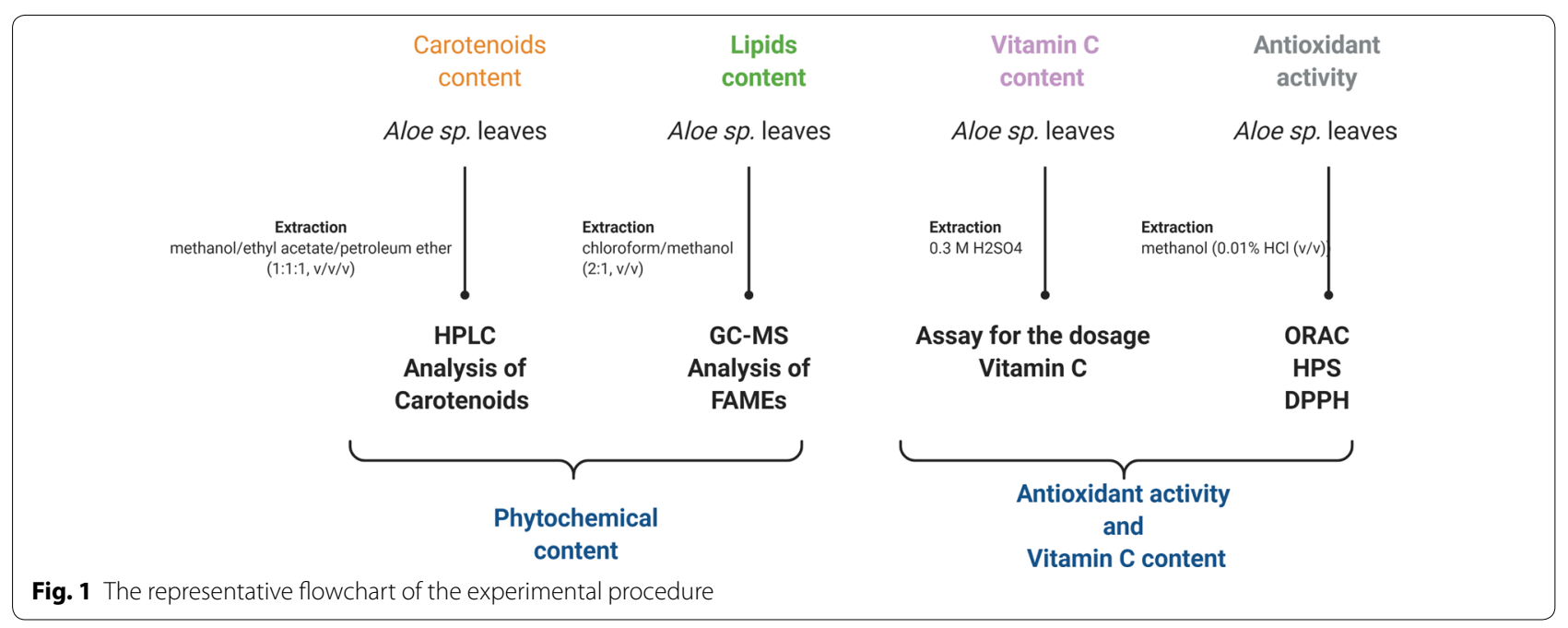


the lipid extraction and fatty acid methyl esters (FAMEs) preparation were all bought from Sigma Aldrich (St. Louis, MO, USA). The FAMEs standard (37-component FAMEMix) was purchased from Supelco (Bellefonte, PA, USA).

Seven different Aloe species: A. aculeata, A. africana, $A$. arborescens, $A$. barbadensis, $A$. ferox and $A$. spectabilis, were kindly supplied by Botanical Garden (Jibou, RO) (Coordinates $48^{\circ} 51^{\prime} 12.28^{\prime \prime} 2^{\circ} 20^{\prime} 55.68^{\prime \prime}$ ). The leaves of each species were collected and homogenized with a high-power homogeniser (MICCRA D-9, Müllheim, DE), in an ice bath, and then stored to $-20{ }^{\circ} \mathrm{C}$ before starting the extraction procedure.

\section{Extraction of carotenoids}

Carotenoids were extracted from $5 \mathrm{~g}$ Aloe leaves using a previously described procedure [25]. After the Aloe's leaves were minced and homogenised, carotenoids were extracted with a mixture of methanol/ethyl acetate/ petroleum ether $(1: 1: 1, \mathrm{v} / \mathrm{v} / \mathrm{v})$. This extraction procedure was repeated three times with the above-mentioned solvent mixture, until the residue became colourless. Then, the extracts of each repetition were mixed, and then the obtained final extract was supposed to a partition with water, diethyl ether and a saline solution. The upper phase formed was collected and evaporated to dryness, and stored at $-80{ }^{\circ} \mathrm{C}$. Prior to the HPLC analysis, the residue was diluted with TBME and filtered (PTFE membrane filters, $0.45 \mu \mathrm{m})$.

\section{HPLC analysis of carotenoids}

Analyses were performed on a Shimadzu HPLC system equipped with a binary pump delivery system LC-20 AT (Prominence), a degasser DGU-20 A3 (Prominence), diode-array SPD-M20 A UV-VIS detector. The column used was YMC C30 $(24 \mathrm{~cm} \times 4.6 \mathrm{~mm}$; particle size $5 \mu \mathrm{m})$. The mobile phase was composed of solvent A: methanol/ TBME/water (81:15:4, v/v/v) and solvent B: TBME/methanol/water (90:7:3, v/v/v). The gradient started with $1 \%$ B at $0 \mathrm{~min}$ and increased to $100 \% \mathrm{~B}$ at $160 \mathrm{~min}$ according to the method described previously [26]. The flow rate was adjusted to $0.8 \mathrm{~mL} / \mathrm{min}$. The DAD operated in the range of 300-600 nm for the acquisition of UV-Vis spectra and the chromatograms were extracted at $450 \mathrm{~nm}$. Individual carotenoids were identified by comparing their retention time, UV-Vis spectra $\left(\kappa_{\max }\right.$, spectral fine structure) with those of the available standards and literature data. The quantitative analysis of carotenoids was based on external calibration using $\beta$-carotene $\left(R^{2}=0.9912\right)$ and lutein $\left(\mathrm{R}^{2}=0.9996\right)$ standard solutions, in the range $1-100 \mu \mathrm{g} /$ $\mathrm{ml}$.

\section{Lipid extraction}

Total lipids were extracted using the classical method described by Folch et al. [27]. Briefly, the extraction was done using a chloroform/methanol mixture. The extraction procedure started with the homogenization of Aloe leaves $(5 \mathrm{~g})$ in methanol using a high-power homogeniser (MICCRA D-9, Müllheim, DE). Then, chloroform was added and the homogenisation procedure continued for another $2 \mathrm{~min}$. The mixture was filtered and the solid residue was suspended in chloroform/methanol (2:1, $\mathrm{v} / \mathrm{v}$ ) and homogenised again for $3 \mathrm{~min}$. After filtration, the residue was further washed with chloroform/methanol $(2: 1, \mathrm{v} / \mathrm{v})$. The filtrates and washes were combined, and then all were washed with $0.88 \%$ aqueous potassium chloride followed by methanol/water $(1: 1, \mathrm{v} / \mathrm{v})$ solution. The purified lipidic layer (bottom) was filtered, dried over anhydrous sodium sulphate, and then evaporated to dry in a rotary evaporator. Total lipids were determined gravimetrically and stored in chloroform at $-20{ }^{\circ} \mathrm{C}$ until were analysed. The recovered oils were transferred to vials with $2 \mathrm{ml}$ chloroform (stock solution) and stored at $-18{ }^{\circ} \mathrm{C}$ until further analysis.

\section{GC-MS analysis of FAMEs}

The fatty acids profile of Aloe species was determined by gas chromatography coupled with mass-spectrometry. Fatty acids were analysed in their methyl ester form. FAMEs were prepared from total lipid extracts using the acid-catalysed transesterification procedure described previously [28]. The esters were extracted twice with hexane; the combined extracts were dried over anhydrous sodium sulphate and filtered. For FAMEs analysis, a Perkin-Elmer Clarus 600T GC-MS was used. The apparatus was equipped with a Supelcowax 10, $60 \mathrm{~m} \times 0.25 \mathrm{~mm}$ i.d., 0.25-m film thickness (Supelco Inc., Bellefonte, PA, USA) capillary column. The injector temperature was set at $210{ }^{\circ} \mathrm{C}$. The oven temperature began at $140{ }^{\circ} \mathrm{C}$, then it was increased to $220^{\circ} \mathrm{C}$ by $7{ }^{\circ} \mathrm{C} / \mathrm{min}$ and was maintained at $220^{\circ} \mathrm{C}$ for $23 \mathrm{~min}$. The flow rate of the carrier gas $\mathrm{He}$ and the split ratio were $0.8 \mathrm{ml} / \mathrm{min}$ and 1:24, respectively. The ionisation energy for the positive ion electron impact (EI) mass spectra was $70 \mathrm{eV}$ with a trap current of 100 $\mu \mathrm{A}$ and a source temperature of $150{ }^{\circ} \mathrm{C}$. Mass scans were performed within the range of $\mathrm{m} / \mathrm{z} 22-395$ at a rate of $0.14 \mathrm{scan} / \mathrm{s}$ with an intermediate time of $0.02 \mathrm{~s}$ between the scans. The injection volume was $0.5 \mu$. FAMEs were identified by comparison of their retention times with those of known standards (37-component FAME Mix, Supelco no. 47885-U) and with mass spectra obtained with compounds from our database (NIST MS Search 2.0). Each fatty acid was expressed as peak area percentage of total fatty acids. 


\section{Vitamin C determination}

The procedure to obtain the extracts and the protocol of the titrimetric method used for the vitamin $C$ determination from the leaves of the selected Aloe species, was described previously [29]. Briefly, $30 \mathrm{~g}$ Aloe leaves were homogenised with $100 \mathrm{ml}$ of $0.3 \mathrm{M} \mathrm{H}_{2} \mathrm{SO}_{4}$ and then the extract was filtrated. $10 \mathrm{ml}$ of filtrated extract was mixed with $30 \mathrm{ml} \mathrm{H}_{2} \mathrm{O}, 5 \mathrm{ml} \mathrm{KI} \mathrm{10 \% ,} 1 \mathrm{ml} \mathrm{H}_{2} \mathrm{SO}_{4}(0.3 \mathrm{M})$ and $10 \mathrm{ml} \mathrm{KIO}_{3}(0.01 \mathrm{M})$. The excess of iodine was titrated against $0.01 \mathrm{M}$ sodium thiosulphate $\left(\mathrm{NaS}_{2} \mathrm{O}_{3}\right)$. The amount of vitamin $\mathrm{C}$ was calculated as a difference of meq $\mathrm{KIO} 3$ and meq $\mathrm{Na}_{2} \mathrm{~S}_{2} \mathrm{O}_{3}$.

\section{Antioxidant activity assays}

For the antioxidant activity analysis, extracts were obtained starting from $5 \mathrm{~g}$ of Aloe leaves grinded with $40 \mathrm{~mL}$ acidified methanol $(0.01 \% \mathrm{HCl}(\mathrm{v} / \mathrm{v}))$ by a homogenizer (Miccra D-9 KT Digitronic, Bergheim, Germany) and then was concentrated to $1 \mathrm{ml}$.

The oxygen radical absorbance capacity (ORAC) was measured and calculated as it was previously described [30]. Briefly, a fluorescein solution $\left(8.16 \times 10^{-5} \mathrm{mM}\right)$ in phosphate buffer $(75 \mathrm{mM}, \mathrm{pH}=7.4)$ was incubated with $25 \mu$ l each standard (Trolox) or sample (Aloe extract) for $30 \mathrm{~min}$, at $37^{\circ} \mathrm{C}$. Then, the reaction was initiated by adding $25 \mu \mathrm{l}$ 2,2'-azobis-2-amidinopropane (AAPH, $153 \mathrm{mM}$ in PBS) and the fluorescence was measured kinetically at excitation wavelength $485 \mathrm{~nm}$ and emission wavelength $535 \mathrm{~nm}$, every minute using the fluorescence microplate reader BioTek (Synergy HT, BioTek Instruments, Winooski, VT). The reported ORAC values were calculated and expressed as $\mu$ mol Trolox equivalents (TE) per liter for gram for solid sample according to ORAC protocol adapted on the microplate reader [30].

The hydrogen scavenging assay (HPS) was carried out following the procedure of Ruch et al. [31]. Briefly, a mixture of $3.4 \mathrm{ml}$ phosphate buffer solution $(1 \mathrm{M}, \mathrm{pH}=7.4)$, $5 \mu \mathrm{l}$ of Aloe extract or Trolox standard and $0.6 \mathrm{ml}$ of $\mathrm{H}_{2} \mathrm{O}_{2}$ (40 $\mathrm{mM}$ in phosphate buffer $1 \mathrm{M}$ with $\mathrm{pH}=7.4$ ) was prepared and its absorbance was read at $230 \mathrm{~nm}$, against a blank solution (phosphate buffer without $\mathrm{H}_{2} \mathrm{O}_{2}$ ). The absorbance was read by a spectrophotometer (JASCO V-630 series, International Co., Ltd., Japan).

The potential to scavenge the 2,2-diphenyl-1-picrylhydrazyl (DPPH) radical was evaluated using the method described by Brand-Williams et al. [32]. Briefly, $250 \mu \mathrm{l}$ of DPPH solution ( $80 \mu \mathrm{M}$ in $95 \%$ methanol) was allowed to react $30 \mathrm{~min}$ in the dark with $35 \mu \mathrm{l}$ Aloe extract and then the absorbance of each sample and standard was measured at $515 \mathrm{~nm}$ [34]. Absorbances were recorded with the microplate reader BioTek (Synergy HT, BioTek Instruments, Winooski, VT). All the values resulted from
ORAC, HPS, DPPH assays were expressed in the same unit, as $\mu \mathrm{mol} \mathrm{TE} / \mathrm{g} \mathrm{FW}$, being calculated similar as in a previous study [33].

\section{Statistical analysis}

PCA analysis. For the characterisation of the studied Aloe species, the data obtained from chromatographic and spectrophotometric analyses was subjected to principal component analysis (PCA) with cross-validation (full model size and centre data), using Unscrambler $\mathrm{X}$ version 10.5 software (CAMO Software AS, Oslo, Norway).

All extractions and chromatographic analyses were performed in triplicate. The results for HPLC, GC-MS analyses and antioxidant assays are presented in tables as the mean \pm standard deviation. Significant differences between samples were analysed with one-way ANOVA post hoc tests and pairwise multiple comparisons were conducted using Tukey's test. Significant differences were reported based on $P<0.05$. Statistical analyses were performed using the SPSS Statistics 23.0.

\section{Results and discussion}

\section{Carotenoid content in whole Aloe leaves extracts}

Reversed Phase High Performance Liquid Chromatography (RP-HPLC) is the analytical technique preferred by researchers for the carotenoids separation, quantification and their structural characterization [34]. The specific spectral characteristics were used for individual carotenoid identification, especially when corroborated with the chromatographic behaviour. In all tested samples, $\beta$-carotene and lutein were identified (Fig. 2), as the predominant $\beta$-carotene and xanthophyll compounds, with a varied ratio among species (Table 1 ).

A. barbadensis leaves proved to have the lowest $\beta$-carotene content $(2.76 \mathrm{mg} / \mathrm{kg})$ among the other species

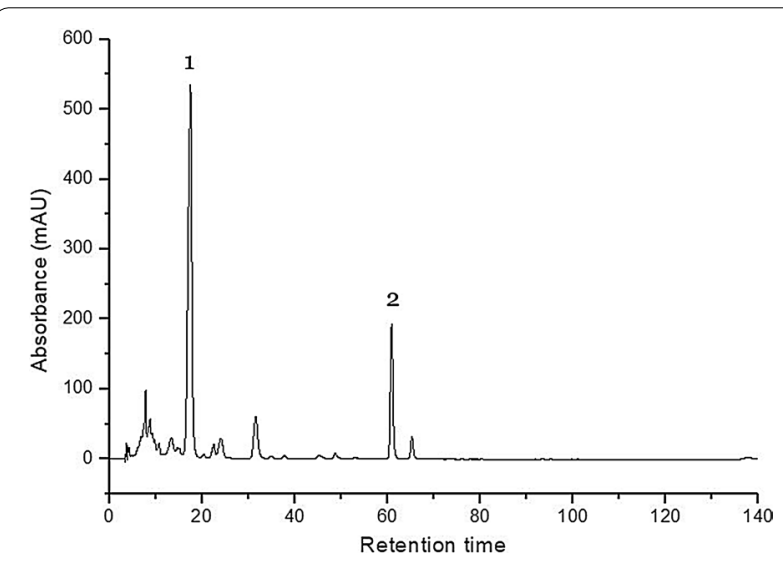

Fig. 2 HPLC chromatogram of carotenoids in Aloe aculeata leaves. Peak 1- Lutein; Peak 2- $\beta$-carotene 
Table 1 Carotenoid and vitamin C composition of Aloe species

\begin{tabular}{|c|c|c|c|c|}
\hline \multirow[t]{2}{*}{ Aloe species } & \multicolumn{4}{|c|}{ Carotenoids mg/kg FW } \\
\hline & Lutein & $\beta$-Carotene & Total carotenoids & $\begin{array}{l}\text { Vitamin C } \\
(\mathrm{mg} / 100 \mathrm{~g} \\
\text { FW) }\end{array}$ \\
\hline Aloe aculeata & $9.02 \pm 0.61^{\mathrm{a}}$ & $7.47 \pm 0.41^{\mathrm{a}}$ & $16.49 \pm 1.20^{\mathrm{a}}$ & $1.17 \pm 0.03^{c}$ \\
\hline Aloe africana & $6.60 \pm 0.19^{b}$ & $3.56 \pm 0.18^{b c}$ & $10.19 \pm 0.27^{c}$ & $2.34 \pm 0.16^{b}$ \\
\hline Aloe arborescens & $5.64 \pm 0.38^{b}$ & $4.12 \pm 0.25^{b}$ & $9.77 \pm 0.25^{c}$ & $2.34 \pm 0.09^{b}$ \\
\hline Aloe barbadensis & $4.00 \pm 0.27^{c}$ & $2.76 \pm 0.14^{d}$ & $6.75 \pm 0.42^{d}$ & $1.16 \pm 0.07^{c}$ \\
\hline Aloe ferox & $9.00 \pm 0.34^{\mathrm{a}}$ & $4.06 \pm 0.25^{b}$ & $13.06 \pm 0.80^{b}$ & $2.34 \pm 1.13^{b}$ \\
\hline Aloe marlothii & $8.43 \pm 0.38^{\mathrm{a}}$ & $7.41 \pm 0.37^{\mathrm{a}}$ & $15.84 \pm 0.52^{\mathrm{a}}$ & $2.01 \pm 0.09^{b}$ \\
\hline Aloe spectabilis & $6.00 \pm 0.26^{b}$ & $3.12 \pm 0.13^{\mathrm{cd}}$ & $9.12 \pm 0.28^{c}$ & $5.85 \pm 0.25^{\mathrm{a}}$ \\
\hline
\end{tabular}

FW fresh weight, SD standard deviation

Values followed by different letters within each column denote a significant difference and those followed by same letters denote no significant difference at $P<0.05$

taken into study, but this content seems to be significantly lower than that observed by Ozsoyet et al. $(15.51 \mathrm{mg} / \mathrm{kg})$ [35]. It has to be taken into account that growing location and some environmental factors could influence the carotenoid composition in Aloe species. In other species as $A$. arborescesns and $A$ ferox the $\beta$-carotene concentrations detected were higher than $\sim 4 \mathrm{mg} / \mathrm{kg} \mathrm{FW}$, but the species with the highest values for $\beta$-carotene concentrations were $A$. aculeata and $A$. marlothii of about $9 \mathrm{mg} /$ kg FW.

A similar tendency as that noted for the $\beta$-carotene content in leaves extracts of Aloe species tested, was observed for the lutein concentration too, which varied within $4.00 \mathrm{mg} / \mathrm{kg}$ (for A. barbadensis) and $9.02 \mathrm{mg} / \mathrm{kg}$ (for A. aculeata) range. However, Aloe aculeata and Aloe ferox have the highest lutein content, which make these species remarkable as the richest ones in carotenoids.

\section{Fatty acid composition in whole Aloe leaves extracts}

The data for the total lipid contents of Aloe leaves, expressed on the basis of fresh weight, are summarized in Table 2. GC-MS analysis revealed the presence of 17 fatty acids, which can be found in leaves of each Aloe species analysed (Fig. 3 and Table 2). Saturated fatty acids (SFA) were identified in the range of $\mathrm{C}_{10}-\mathrm{C}_{24}$. One of the saturated fatty acid found in all leaves of Aloe species was palmitic acid (C16:0). As can be seen in the Table 2, Aloe aculeata and Aloe barbadensis possess in their leaves the highest percent of palmitic acid, of about 24.13, respective 26.48 comparing to other Aloe species. Another saturated fatty acid identified in samples was stearic acid (C18:0) in Aloe africana, respective Aloe spectabilis. The most prominent polyunsaturated fatty acids found in Aloe leaves were linoleic acid (C18:2 $n-6)$ and linolenic acid $(C 18: 3 n-3)$. In particular, linoleic acid $(\mathrm{C} 18: 2 \mathrm{n}-6)$ was found in higher percent in
Aloe spectabilis, Aloe arborescens and Aloe ferox leaves, values ranged from 19.61 to 22.5 percent. Regarding linolenic acid $(C 18: 3 n-3)$, it is highly represented in all species apart of Aloe aculeata, in which it is less represented with about $15-20 \%$. These two polyunsaturated fatty acids comprise about $50 \%$ of the fatty acids of Aloe leaves (Table 2).

Cis-7 hexadecenoic acid (C16:1 $\mathrm{n}-7)$ and oleic acid $(\mathrm{C} 18: 1 \mathrm{n}-9)$ were better represented in Aloe aculeata leaves compared to the other species analyzed. The content of oleic acid $(18: 1 \mathrm{n}-9)$ was quite similar with that of stearic acid (18:0) in all Aloe species, with average percentage of 7.28 (between 7.00 and 7.73) and 5.12 (4.395.85), respectively.

Aloe aculeata distinguishes itself from the other species having a different fatty acids profile, with palmitic acid $(24.13 \%)$ and linolenic acid $(19.50 \%)$ as the major fatty acids. Interesting is the fact that also oleic acid $(\mathrm{C} 18: 1 \mathrm{n}-9,18.46 \%)$ and palmitoleic acid $(16: 1 \mathrm{n}-7$, $14.16 \%$ ) were higher represented in A. aculeata, comparing to other species.

Traces of capric acid (C10:0), lauric acid (C12:0), myristic acid (14:0), pentadecanoic acid (C15:0), margaric acid (C17:0), arachidonic acid (C20:0), behenic acid (C22:0), trycosilic acid (C23:0), lignoceric acid (C24:0) were found in all species of Aloe leaves taken into study. It is also interesting to note the relatively high percentage of the very long chain fatty acids $\left(>20^{\circ} \mathrm{C}\right)$ in $A$. africana, A. arborescens, A.barbadensis, A.marlothii and $A$. spectabilis.

Regarding the saturated fatty acid (SFA) representation, significant differences $(\mathrm{P}<0.05)$ between the species can be seen (Table 2). Aloe ferox presented the highest PUFAs percentage 60.15 and the lowest in SFAs 29.20 compared to the other species, all differences being statistically significant. A significant PUFAs, 
Table 2 Fatty acid composition of total lipids extracted from Aloe species

\begin{tabular}{|c|c|c|c|c|c|c|c|c|}
\hline No. & Fatty acid (\%)* & Aloe aculeata & Aloe africana & Aloe arborescens & Aloe barbadensis & Aloe ferox & Aloe marlothii & Aloe spectabilis \\
\hline 1 & Capric acid (C10:0) & $0.04 \pm 0.00^{e}$ & $0.17 \pm 0.00^{b}$ & $0.19 \pm 0.01^{\mathrm{a}}$ & $0.09 \pm 0.00^{d}$ & $0.02 \pm 0.00^{f}$ & $0.08 \pm 0.00^{d}$ & $0.12 \pm 0.01^{c}$ \\
\hline 2 & Lauric acid (C12:0) & $0.24 \pm 0.01^{f}$ & $0.64 \pm 0.03^{b}$ & $0.56 \pm 0.02^{c}$ & $0.42 \pm 0.02^{d}$ & $0.32 \pm 0.01^{e}$ & $0.51 \pm 0.02^{c}$ & $0.73 \pm 0.03^{\mathrm{a}}$ \\
\hline 3 & Myristic acid (C14:0) & $0.83 \pm 0.04^{f}$ & $2.54 \pm 0.12^{\mathrm{a}}$ & $2.09 \pm 0.10^{b}$ & $1.01 \pm 0.05^{e f}$ & $1.44 \pm 0.07^{d}$ & $1.09 \pm 0.05^{\mathrm{e}}$ & $1.73 \pm 0.08^{c}$ \\
\hline 4 & $\begin{array}{l}\text { Pentadecyclic acid } \\
\text { (C15:0) }\end{array}$ & $0.26 \pm 0.01^{\mathrm{e}}$ & $0.54 \pm 0.01^{b c}$ & $0.78 \pm 0.05^{\mathrm{a}}$ & $0.46 \pm 0.02^{d}$ & $0.51 \pm 0.04^{\mathrm{bcd}}$ & $0.5 \pm 0.02^{c d}$ & $0.58 \pm 0.02^{b}$ \\
\hline 5 & Palmitic acid (C16:0) & $24.13 \pm 1.17^{a b}$ & $22.42 \pm 1.11^{b c}$ & $21.70 \pm 1.12^{b c}$ & $26.48 \pm 1.38^{\mathrm{a}}$ & $20.44 \pm 0.99^{c}$ & $24.48 \pm 1.23^{\mathrm{ab}}$ & $20.65 \pm 0.98^{c}$ \\
\hline 6 & $\begin{array}{l}\text { Palmitoleic acid } \\
(C 16: 1 n-9)\end{array}$ & $0.53 \pm 0.02^{d}$ & $1.44 \pm 0.07^{b}$ & $3.25 \pm 1.15^{\mathrm{a}}$ & $0.91 \pm 0.04^{c}$ & $1.61 \pm 0.81^{b}$ & $1.08 \pm 0.05^{c}$ & $1.48 \pm 0.72^{b}$ \\
\hline 7 & $\begin{array}{l}\text { Cis-7 hexadecenoic } \\
\text { acid }(C 16: 1 n-7)\end{array}$ & $14.16 \pm 0.72^{\mathrm{a}}$ & $0.48 \pm 0.02^{d}$ & $0.37 \pm 0.01^{d}$ & $2.81 \pm 0.13^{b}$ & $0.89 \pm 0.04^{\text {cd }}$ & $1.56 \pm 0.08^{c}$ & $0.65 \pm 0.03^{d}$ \\
\hline 8 & Margaric acid (C17:0) & $0.54 \pm 0.02^{f}$ & $1.14 \pm 0.06^{\mathrm{d}}$ & $0.83 \pm 0.04^{e}$ & $1.93 \pm 0.09^{\mathrm{a}}$ & $0.85 \pm 0.04^{e}$ & $1.73 \pm 0.08^{b}$ & $1.52 \pm 0.07^{c}$ \\
\hline 9 & Stearic acid (C18:0) & $4.61 \pm 0.23^{c}$ & $5.72 \pm 0.28^{\mathrm{a}}$ & $5.35 \pm 0.27^{\mathrm{ab}}$ & $4.69 \pm 0.22^{b c}$ & $4.74 \pm 0.23^{b c}$ & $4.39 \pm 0.22^{c}$ & $5.85 \pm 0.28^{\mathrm{a}}$ \\
\hline 10 & $\begin{array}{l}\text { Oleic acid (C18:1 } \\
n-9)\end{array}$ & $18.46 \pm 0.94^{\mathrm{a}}$ & $7.03 \pm 0.34^{b}$ & $7.08 \pm 0.33^{b}$ & $7.73 \pm 0.39^{b}$ & $7.26 \pm 0.34^{b}$ & $7.53 \pm 0.37^{b}$ & $7.00 \pm 0.35^{b}$ \\
\hline 11 & $\begin{array}{l}\text { Vaccenic acid (C18:1 } \\
\quad n-7)\end{array}$ & $5.03 \pm 0.24^{a}$ & $1.34 \pm 0.06^{b}$ & $0.55 \pm 0.02^{e}$ & $1.23 \pm 0.06^{b c}$ & $0.89 \pm 0.04^{d}$ & $1.03 \pm 0.05^{\mathrm{cd}}$ & $0.98 \pm 0.05^{\mathrm{cd}}$ \\
\hline 12 & $\begin{array}{l}\text { Linoleic acid (C18:2 } \\
n-6)\end{array}$ & $10.75 \pm 0.54^{e}$ & $17.37 \pm 1.85^{c d}$ & $19.92 \pm 0.62^{\mathrm{ab}}$ & $15.67 \pm 0.81^{d}$ & $19.61 \pm 1.00^{b c}$ & $17.77 \pm 0.93^{\mathrm{bcd}}$ & $22.25 \pm 1.07^{a}$ \\
\hline 13 & $\begin{array}{l}\text { Linolenic acid (C18:3 } \\
n-3)\end{array}$ & $19.50 \pm 0.97^{c}$ & $36.43 \pm 1.81^{\mathrm{ab}}$ & $34.74 \pm 1.72^{b}$ & $36.94 \pm 1.79^{\mathrm{ab}}$ & $40.55 \pm 2.03^{a}$ & $37.89 \pm 1.95^{\mathrm{ab}}$ & $33.55 \pm 1.68^{b}$ \\
\hline 14 & $\begin{array}{l}\text { Arachidonic acid } \\
\text { (C20:0) }\end{array}$ & $0.29 \pm 0.01^{c}$ & $0.57 \pm 0.02^{b}$ & $0.77 \pm 0.04^{\mathrm{a}}$ & $0.73 \pm 0.03^{a}$ & $0.23 \pm 0.01^{c}$ & $0.71 \pm 0.03^{\mathrm{a}}$ & $0.69 \pm 0.03^{a}$ \\
\hline 15 & Behenic acid (C22:0) & $0.20 \pm 0.01^{d}$ & $0.65 \pm 0.03^{c}$ & $1.02 \pm 0.04^{\mathrm{a}}$ & $0.69 \pm 0.03^{b c}$ & $0.22 \pm 0.01^{\mathrm{cd}}$ & $0.73 \pm 0.03^{b c}$ & $0.76 \pm 0.03^{b}$ \\
\hline 16 & $\begin{array}{l}\text { Tricosylic acid } \\
\text { (C23:0) }\end{array}$ & $0.09 \pm 0.00^{e}$ & $0.51 \pm 0.02^{\mathrm{a}}$ & $0.22 \pm 0.01^{c}$ & $0.41 \pm 0.02^{b}$ & $0.16 \pm 0.01^{d}$ & $0.38 \pm 0.02^{b}$ & $0.52 \pm 0.02^{\mathrm{a}}$ \\
\hline \multirow[t]{7}{*}{17} & $\begin{array}{l}\text { Lignoceric acid } \\
\text { (C24:0) }\end{array}$ & $0.33 \pm 0.02^{d}$ & $1.02 \pm 0.05^{\mathrm{a}}$ & $0.60 \pm 0.03^{c}$ & $0.80 \pm 0.03^{b}$ & $0.26 \pm 0.01^{d}$ & $0.75 \pm 0.03^{b}$ & $0.95 \pm 0.05^{\mathrm{a}}$ \\
\hline & $\sum$ SFAs & $31.57 \pm 1.63^{\mathrm{ab}}$ & $35.91 \pm 1.75^{\mathrm{a}}$ & $34.09 \pm 1.63^{\mathrm{a}}$ & $34.72 \pm 1.70^{\mathrm{a}}$ & $29.21 \pm 1.39^{b}$ & $35.35 \pm 1.76^{\mathrm{a}}$ & $34.10 \pm 1.68^{\mathrm{a}}$ \\
\hline & $\sum M U F A s$ & $38.18 \pm 1.93^{\mathrm{a}}$ & $10.29 \pm 0.52^{b c}$ & $11.26 \pm 0.55^{b c}$ & $12.67 \pm 0.62^{b}$ & $10.64 \pm 0.55^{b c}$ & $11.20 \pm 0.56^{b c}$ & $10.10 \pm 0.49^{c}$ \\
\hline & $\sum$ PUFAs & $30.25 \pm 1.58^{c}$ & $53.80 \pm 2.68^{\mathrm{ab}}$ & $54.65 \pm 2.73^{\mathrm{ab}}$ & $52.61 \pm 2.52^{b}$ & $60.15 \pm 3.15^{a}$ & $55.69 \pm 2.68^{\mathrm{ab}}$ & $55.80 \pm 2.72^{\mathrm{ab}}$ \\
\hline & PUFAs/SFAs & $0.96- \pm 0.04^{c}$ & $1.50 \pm 0.08^{b}$ & $1.60 \pm 0.08^{b}$ & $1.52 \pm 0.08^{b}$ & $2.06 \pm 0.10^{\mathrm{a}}$ & $1.52 \pm 0.08^{b}$ & $1.64 \pm 0.09^{b}$ \\
\hline & $n-6 / n-3$ PUFAs & $0.55 \pm 0.02^{b c}$ & $0.48 \pm 0.02^{c d}$ & $0.57 \pm 0.03^{b}$ & $0.42 \pm 0.04^{d}$ & $0.48 \pm 0.02^{c d}$ & $1.64 \pm 0.09^{b}$ & $0.66 \pm 0.03^{\mathrm{a}}$ \\
\hline & $\begin{array}{l}\text { Total lipid content } \\
(\mathrm{g} / 100 \mathrm{~g} \mathrm{FW})\end{array}$ & $2.768 \pm 0.32^{d}$ & $3.086 \pm 0.81^{c}$ & $3.121 \pm 0.82^{c}$ & $3.173 \pm 0.56^{c}$ & $4.105 \pm 0.49^{b}$ & $3.995 \pm 0.37^{b}$ & $4.323 \pm 0.93^{\mathrm{a}}$ \\
\hline
\end{tabular}

* \% of total fatty acids; values are expressed as mean \pm standard deviation. Values followed by different letters within each column denote a significant difference and those followed by same letters denote no significant difference at $\mathrm{P}<0.05$

monounsaturated fatty acids (MUFAs), and SFAs percentage were seen in $A$. africana, $A$. arborescens, $A$. barbadensis, A. marlothii, and A. spectabilis, with no significant variations between these species, the medium values being 54.51, 34.83, and 11.10 , respectively. The PUFAs/SFAs ratios were $\geq 1.50$ in six out of seven Aloe species, and among all A. ferox ratio being significantly higher. Overall, no major differences were observed in terms of the $n-6 / n-3$ PUFAs ratio. Interestingly, $A$. aculeata presented a more balanced composition concerning the type of fatty acid. MUFAs had the highest proportion (38.18\%), significantly higher than the other species, followed by SFAs (31.57\%) and PUFAs (30.25\%).
As far as we known, there are no data available regarding the fatty acid composition of Aloe leaves, only few studies were found about fatty acids existence in gel leaves of Aloe. But, in the leaf gel of Aloe ferox was found that the major fatty acid is linoleic acid, which represent a value $\sim$ twofold and $\sim 68$-fold higher than that for palmitic acid and $\alpha$-linolenic acid [13]. In contrast, in the leaf gel of Aloe barbadensis the major fatty acid found was linoleic acid [4], whereas in the flowers of Aloe barbadensis species the representative fatty acids are myristoleic acid (C14:1 $\mathrm{n}-9,31.2 \%)$ and palmitic acid (C16:0, 22.86\%) [36]. The total lipid analysis of eight Aloe gels (including from Aloe barbadensis, Aloe arborescens and Aloe ferox) revealed a difference among species regarding the 


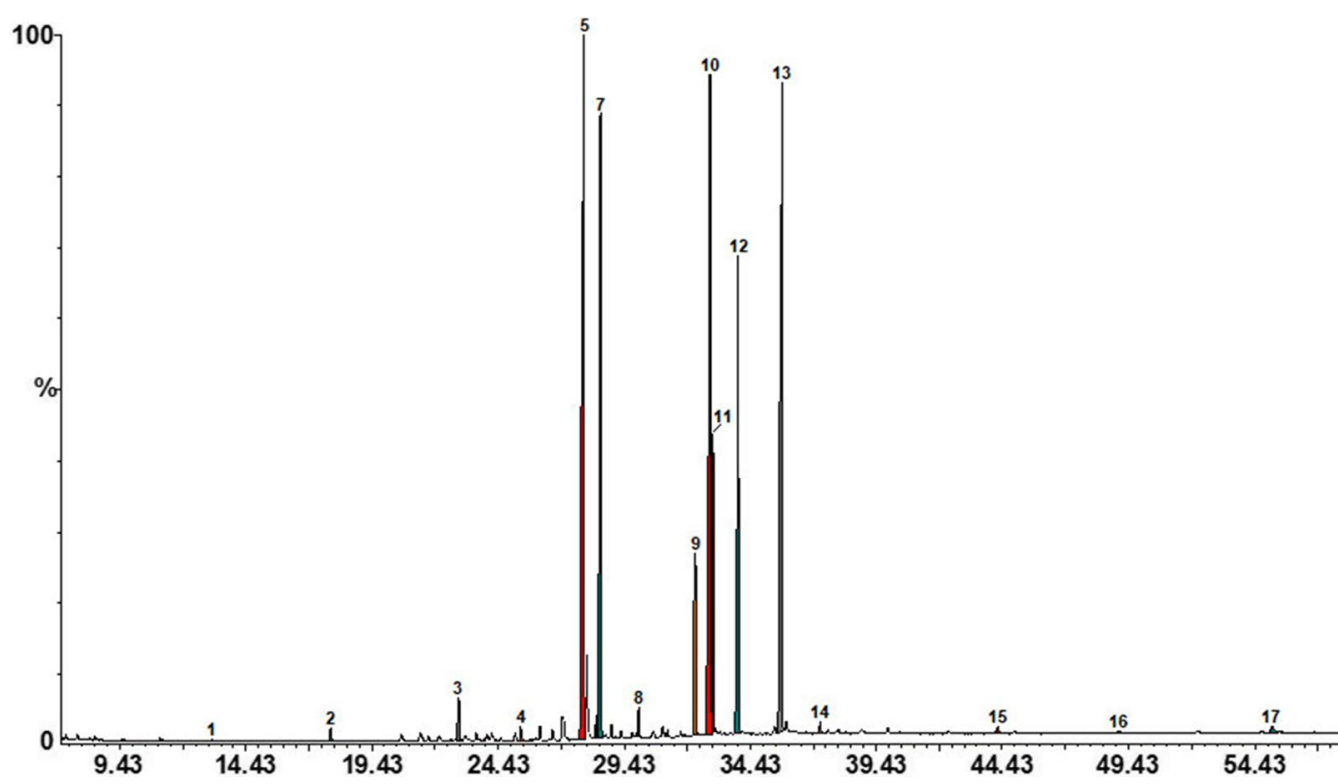

Fig. 3 Characteristic GC-MS chromatogram of the fatty acids profile of Aloe aculeata leaves. The numbers written on chromatogram correspond to the identified fatty acids accordingly: 1-Capric acid (C10:0), 2-Lauric acid (C12:0), 3-Myristic acid (C14:0), 4-Pentadecyclic acid (C15:0), 5-Palmitic acid (C16:0), 6-Palmitoleic acid (C16;1, $n$ - 9), 7-Cis-7 hexadecenoic acid (C16:1, $n-7)$, 8-Margaric acid (C17:0), 9-Stearic acid (C18:0), 10-Oleic acid (C18:1, $n-9), 11$-Vaccenic acid (C18:1 n-7), 12-Linoleic acid (C18:2 n-6), 13-Linolenic acid (C18:3 n-3), 14-Arachidonic acid (C20:0), 15-Behenic acid (C22:0), 16-Tricosylic acid (C23:0), 17-Lignoceric acid (C24:0)

concentration of fatty acids [37]. Aloe arborescens contains significantly higher concentration of fatty acids than Aloe ferox or Aloe barbadensis, which means that a higher concentration of fatty acids indicate the existence of an efficient coat of the plant working as a barrier toward stress factors [38].

There are several studies which sustain that low values of the dietary $n-6 / n-3$ essential fatty acids (ranging from 1 to 5) and PUFAs/SFAs (ranging from 1 to 1.5) ratios can reduce significantly the risk of cardiovascular disease and cancer [16]. Moreover, among polyunsaturated fatty acids (PUFAs), linoleic acid has been shown to be the most potent fatty acid for lowering the plasma triacylglycerols, low-density and high-density lipoprotein cholesterol [17].

\section{Vitamin C content}

Aloe spectabilis compared with all other species showed the highest content in vitamin $\mathrm{C}$, while other species like $A$. africana, $A$. arborescens, and $A$. ferox presented all similar values (Table 1). Vega-Gálvez et al. in a study done to observe the effects of high pressures (500 MPa) on vitamin $\mathrm{C}$ content from Aloe vera gel, measured an initial content of $126.37 \mathrm{mg} / 100 \mathrm{~g}$ dry weight [39].

\section{PCA analysis}

The data resulted from carotenoids, fatty acids and vitamin $\mathrm{C}$ analyses were subjected to the Principal
Component Analysis (PCA) in order to underline the samples' similarities and differences based on their specific chemical composition. In this regard a matrix containing the 7 Aloe vera samples and 21 variables for each sample (including concentration values for 17 fatty acids, lutein, $\beta$-carotene, vitamin $C$ and total amount of carotenoids) was computed. The calculation was performed using a mean center data model (which allows to subtract the column means from every variable before analysis), with cross validation and single value decomposition algorithm. Thus, using this chemometric method, the two principal components explained $88 \%$ of the overall variance ( $77 \%$ and $11 \%$ for PC-1 and PC-2, respectively) dividing the studied samples into 3 distinct clusters (Fig. 4). The first cluster included $A$. barbadensis, $A$. spectabilis, $A$. arborescens and $A$. africana, the second $A$. ferox and $A$. marlothii and the third one is represented by $A$. aculeata, which has a very distinctive pattern compared to other Aloe samples.

The correlation loadings bi-plot was also computed in order to point out the correlations between Aloe species and determined bioactive compounds (Fig. 5). The compounds within the inner ellipse indicate $50 \%$ of explained variance, while the outer ellipse indicates $100 \%$ of explained variance. In this way, the importance of individual variables is visualized more clearly. Thus, in the case of $A$. aculeata, the correlation loading bi-plot 


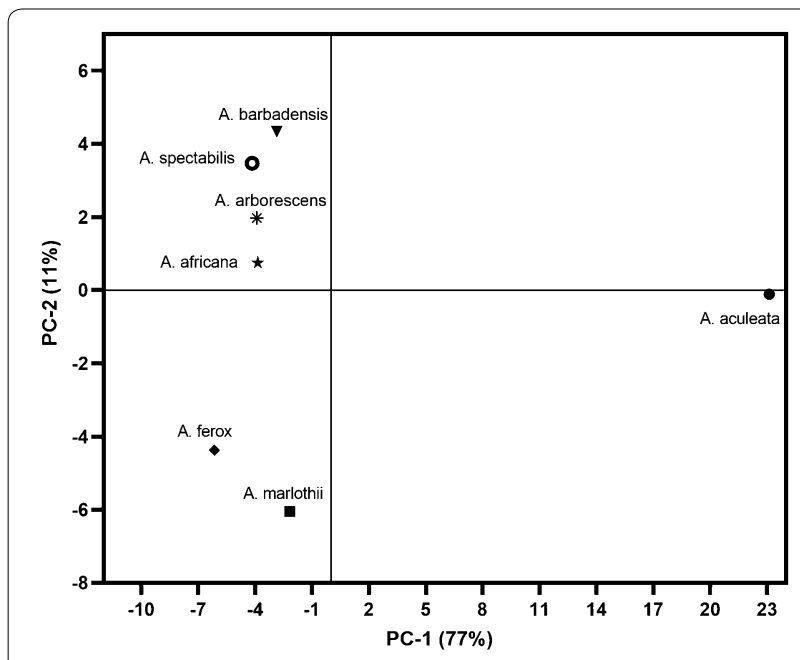

Fig. 4 Principal components analysis bi-plots of 7 Aloe species based on their fatty acids profiles, carotenoids and vitamin C content. The first two components together explained $88 \%$ of the data variation

(Fig. 5) highlighted three marker compounds, namely: C18:1n $-7, C 18: 1 n-9$ and C16:1n -7 fatty acids.

\section{Antioxidant activity}

Since antioxidant molecules (e.g., ascorbate, carotenoids) could add an extra value in pharmaceutical products for instance, we evaluated the potential antioxidant activity for the Aloe leaves extracts. Three different assays such as $\mathrm{DPPH}, \mathrm{ORAC}$, and HPS were used to evaluate the free radical scavenging potential of the Aloe leaves extracts (Fig. 6). The scavenging potential against peroxyl radical of Aloe species was assessed by ORAC assay revealed that the highest ORAC values were obtained for Aloe arborescens and Aloe marlothii. Regarding the HPS assay assessment, Aloe arborescens and Aloe marlothii, followed by Aloe ferox and Aloe spectabilis proved to have the highest potential to scavenge hydrogen peroxide, known as toxic by-product of the oxygen metabolism in viable cells.

Based on three different assays, $A$. arborescens proved to exert the highest scavenging activity $(60 \mu \mathrm{mol} \mathrm{TE} / \mathrm{g}$ FW for DPPH assay, $2600 \mu \mathrm{mol} \mathrm{TE} / \mathrm{g} \mathrm{FW}$ for ORAC assay, and $43.35 \mu \mathrm{mol}$ TE/g FW for HPS assay) followed by $A$. marlothii $(55 \mu \mathrm{mol} \mathrm{TE} / \mathrm{g}$ FW, $1876 \mu \mathrm{mol} \mathrm{TE} / \mathrm{g}$ FW, and $42.00 \mu \mathrm{mol} \mathrm{TE} / \mathrm{g} \mathrm{FW})$. Certainly, both carotenoids and vitamin $C$ contributed to the antioxidant activity of $A$. arborescens extract. However, there are other compounds with antioxidant potential in the extracts, since Aloe spectabilis and Aloe ferox also have a high carotenoid and vitamin $\mathrm{C}$ content, but had a lower antioxidant activity than Aloe arborescens.

Our observations seem to be consistent with those available in scientific literature. For example, in one study the phytochemical profile and the antioxidant activity of different leaf portions of $A$. arborescens and $A$. barbadensis were compared. It was found that the ORAC

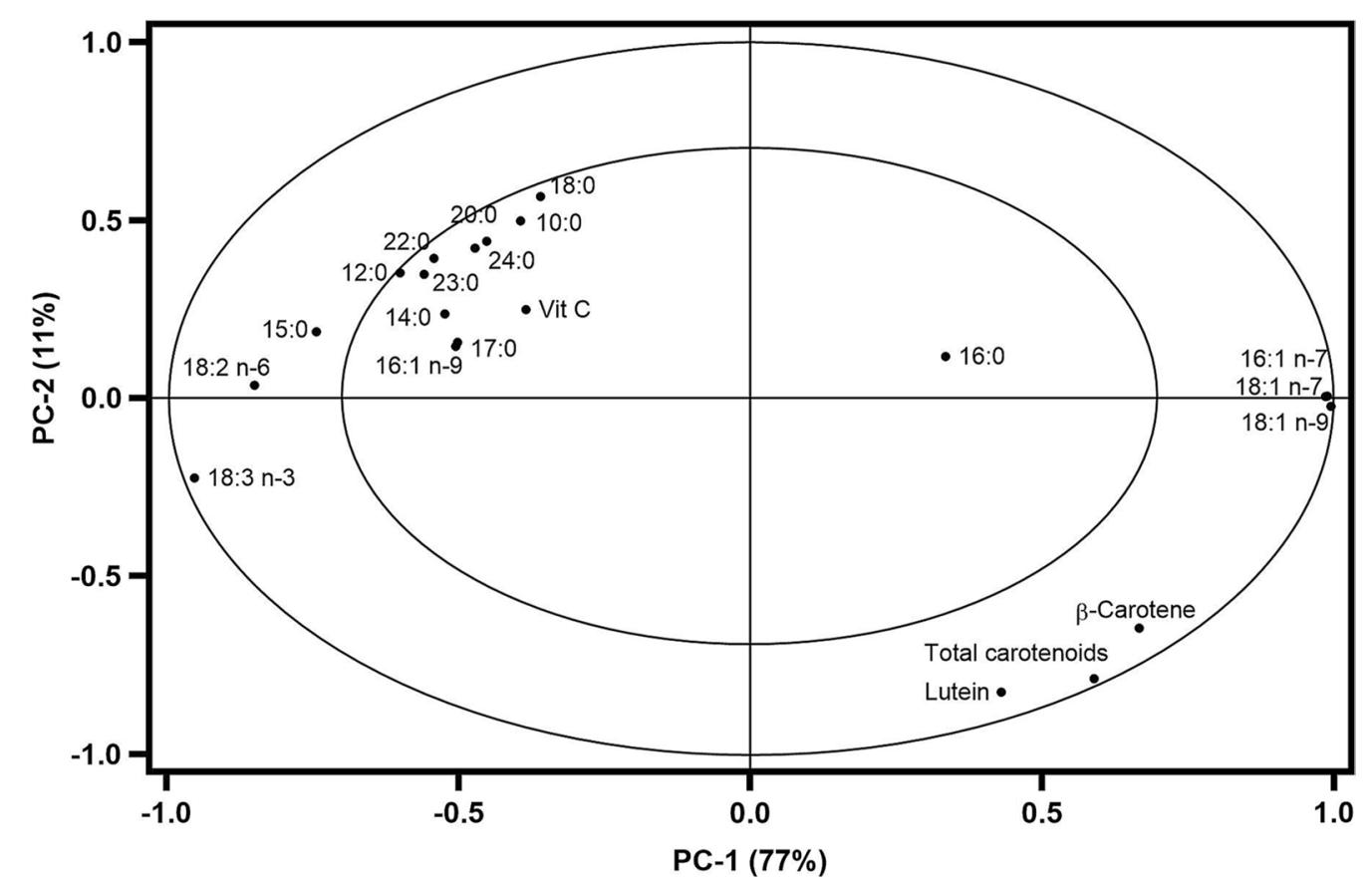

Fig. 5 Correlation loadings bi-plots for the Aloe samples 


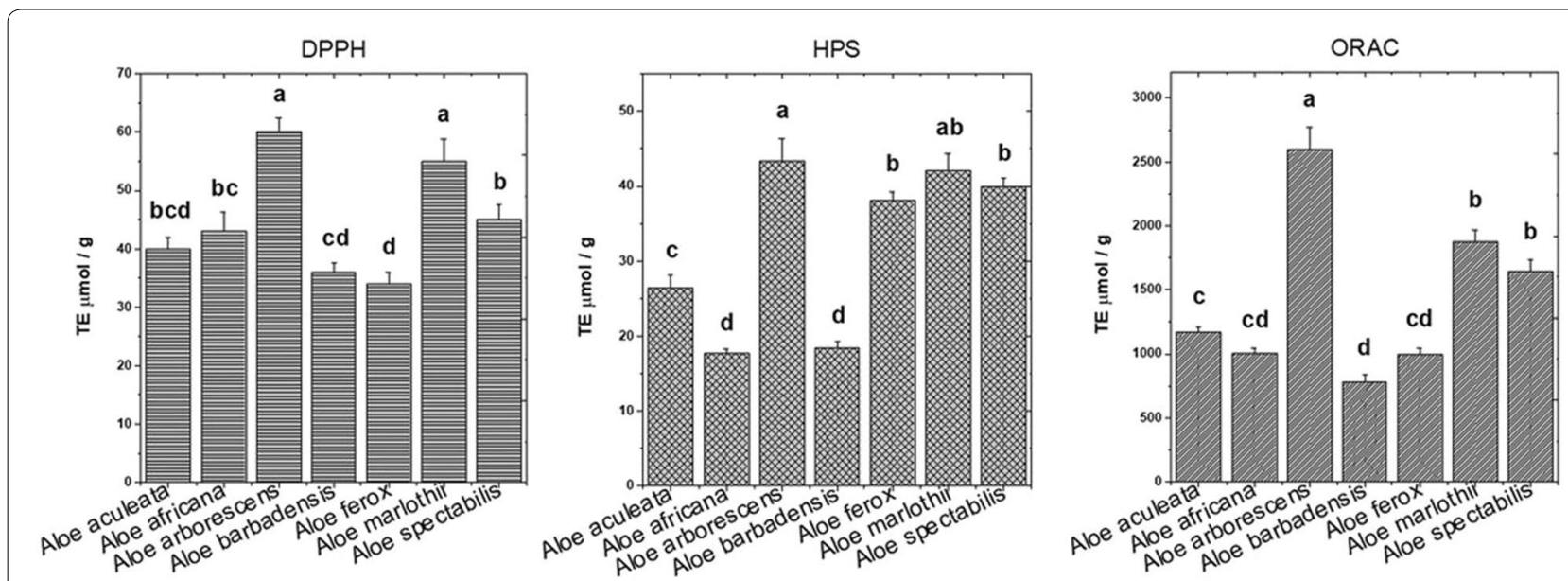

Fig. 6 Antioxidant activities of the whole leaf extracts of Aloe species, resulted according to DPPH, ORAC, HPS radical scavenging assays. Values followed by different letters within each column denote a significant difference and those followed by same letters denote no significant difference at $P<0.05$. Error bars represent standard deviation (SD) from three independent experiments

radical scavenging potential was higher for $A$. arborescens than for $A$. barbadensis, while the DPPH assay indicated a reversed order, without a statistic significance [3]. When ORAC values of seven Aloe species were compared, the highest value was reported for $A$. arborescens (2135.1 $\mu \mathrm{mol}$ TE/100 g FW), which was significantly higher than that for $A$. ferox $(525.72 \mu \mathrm{mol} \mathrm{TE} / 100 \mathrm{~g} \mathrm{FW})$, and $A$. barbadensis (1234.4 $\mu \mathrm{mol}$ TE/100 g FW) [10]. In the study conducted by Cardarelli et al. the scavenging activity profiles obtained by DPPH and ORAC assays, followed the trend $A$. marlothii $<A$. ferox $<$ A.arborescens $<A$. barbadensis [1]. Similar ORAC radical scavenging activities were obtained for $A$. barbadensis and $A$. ferox, when the lyophilized leaf gel and the ethanolic leaf extracts were compared $[4,13]$.

Here, from all analysed species, $A$. arborescens, $A$. marlothii, and $A$. spectabilis had a similar potential to scavenge the hydrogen peroxide by HPS assay, but among this species, $A$. arborescens had the highest scavenge potential $(43.35 \mu \mathrm{mol} \mathrm{TE} / \mathrm{g} \mathrm{FW})$. In contrast, a low scavenging activity was observed for $A$. africana $(17.72 \mu \mathrm{mol} \mathrm{TE} / \mathrm{g}$ FW) and $A$. barbadensis $(18.43 \mu \mathrm{mol} \mathrm{TE} / \mathrm{g} \mathrm{FW})$. In a recent study, it was proved that the agro-climatic conditions could affect phytochemicals, the Total Phenolic Content (TPC) and the antioxidant potential of $A$. barbadensis. Thus, the antioxidant potential of $A$. barbadensis was reduced to 58.54 to $81.10 \%$ based on HPS assay [18].

The determined antioxidant activity of $A$. ferox in ethanol, methanol, acetone and aqueous extracts by using the HPS assay, proved that the percentage inhibitions of hydrogen peroxide were dependent on solvent concentration and induced different effects, in the following order: acetone $<$ ethanol $<$ gallic acid $<$ methanol $<$ BHT (butylated hydroxytoluene)<aqueous extract [15]. Apart the solvent used for extraction it is known that there are other factors which could influence the antioxidant capacity in Aloe leaves such as the extraction procedure and the quantity of active compounds which exist in the parts of the plant subjected to analysis. Some authors demonstrated that the leaf skin extract exhibited the highest antioxidant activity as compared to flowers or inner parenchyma and whole leaf extracts $[3,35]$. Strong correlations were established between the polyphenols and flavonoids content of leaf skin and its scavenging activity [24]. On the other hand, other researchers postulated that polysaccharides from the inner parenchyma were the main contributors to the antioxidant properties of the plant [40].

A relatively reduced radical scavenging activity of $A$. barbadensis found in this study (Fig. 6) might be associated with its lowest total carotenoid and vitamin $C$ contents (Table 1). In a similar way, the highest antioxidant content in A. marlothii is reflected in an increased radical scavenging activity when compared to other species. Amongst all species, A. spectabilis occupy the third rank of the highest antioxidant activities, which might be ascribed also to its higher vitamin $\mathrm{C}$ content.

\section{Conclusions}

The main carotenoids identified in all six Aloe leaves extracts studied were lutein and $\beta$-carotene. Therefore, Aloe aculeata and Aloe ferox species might be taken into consideration as sources of carotenoids, of which Aloe aculeata is the richest one in $\beta$-carotene and Aloe ferox in lutein. 
According to GC-MS analysis 17 fatty acids were detected in leaves of each of Aloe species analysed. The most representative saturated fatty acid found in all Aloe species leaves was palmitic acid (C16:0), in a higher percentage being expressed in Aloe aculeata and Aloe barbadensis. As polyunsaturated fatty acids, linoleic acid $(\mathrm{C} 18: 2 \mathrm{n}-6)$ and linolenic acid (C18:3 n-3), were better represented in Aloe spectabilis, Aloe arborescens and Aloe ferox leaves.

Moreover, Aloe aculeata has a remarkable MUFA content, by the high percentage being represented cis-7 hexadecenoic acid (C16:1 $n-7)$, respectively oleic acid $(C 18: 1 \mathrm{n}-9)$. The PCA Analysis formulates a comprehensive framework encompassing the seven Aloe species in respect to carotenoid, fatty acid and vitamin $C$ content. Therefore, it can be concluded that Aloe aculeata has a particular fatty acid content, characterised by vaccenic acid $(C 18: 1 n-7)$, oleic acid $(C 18: 1 n-9)$ and cis-7 hexadecenoic (C16:1n - 7) fatty acid. But, Aloe aculeata could be considered a rich source of carotenoids too. However, all other particular findings in other Aloe leaves extracts should be valued accordingly. Aloe arborescens and Aloe marlothii, followed by Aloe ferox and Aloe spectabilis proved to have the highest potential to scavenge reactive oxygen species.

Though the most literature data are mainly focused on Aloe barbadensis, more attention should be paid to the usage of other less-known Aloe species in research and industry.

\section{Abbreviations \\ DAD: Diode array detection; DPPH: 2,2-Diphenyl-1-picrylhydrazyl; GC-MS: Gas chromatography coupled with mass spectrometry; HPLC: High performance liquid chromatography; HPS: Hydrogen peroxide scavenging; ORAC: Oxygen radical absorbance capacity; FAMEs: Fatty acid methyl esters; meq: Mil- liequivalents; MUFA: Monounsaturated fatty acids; PUFA: Polyunsaturated fatty acids; PCA: Principle component analysis; SFA: Saturated fatty acids; TE: Trolox equivalent; TBME: Tert-butyl methyl ether; TIC:Total ion current; TPC: Total phenolic content.}

\section{Acknowledgements}

Authors thank Botanical Garden from Jibou for their kind donation of leaves from Aloe species studied.

\section{Author's contributions}

Conceptualization and methodology (HPLC analysis) was done by BA; CF (antioxidant activity assays), DF (GC-MS analysis), VA (Vitamin C analysis); SS (PCA analysis); RD was responsible by writing, review and editing; supervision was offered by PA. Authorship was limited to those who have contributed substantially to the work reported. All authors read and approved the final manuscript.

\section{Funding}

This research was funded by the Ministry of Research and Innovation through Development of the National Research and Development System Program, Grant Number 37PFE/06.11.2018.

\section{Availability of data and materials}

The data used to support the findings of this study are available from the corresponding author upon request.
Ethics approval and consent to participate Not applicable.

\section{Consent for publication}

The manuscript has been read and approved by all named authors and that there are no other persons who satisfied the criteria for authorship but are not listed.

\section{Competing interests}

The authors declare no competing interest. The founding sponsors had no role in the design of the study; in the collection, analyses, or interpretation of data; in the writing of the manuscript, and in the decision to publish the results.

\section{Author details}

${ }^{1}$ Faculty of Animal Science and Biotechnologies, University of Agricultural Sciences and Veterinary Medicine, Calea Manastur, No. 3-5, 400372 Cluj-Napoca, Romania. ${ }^{2}$ Faculty of Veterinary Medicine, University of Agricultural Sciences and Veterinary Medicine, Calea Manastur, No. 3-5, 400372 Cluj-Napoca, Romania. ${ }^{3}$ Faculty of Agriculture, University of Agricultural Sciences and Veterinary Medicine, Calea Manastur, No. 3-5, 400372 Cluj-Napoca, Romania. ${ }^{4}$ Faculty of Food Science, University of Agricultural Sciences and Veterinary Medicine, Calea Manastur, No. 3-5, 400372 Cluj-Napoca, Romania.

Received: 22 July 2020 Accepted: 21 October 2020

Published online: 31 October 2020

\section{References}

1. Cardarelli M, Rouphael Y, Pellizzoni M, Colla G, Lucini L (2017) Profile of bioactive secondary metabolites and antioxidant capacity of leaf exudates from eighteen Aloe species. Ind Crops Prod 108:44-51. https://doi. org/10.1016/j.indcrop.2017.06.017

2. Cousins SR, Witkowski ETF (2012) African aloe ecology: a review. J Arid Environ 85:1-17. https://doi.org/10.1016/j.jaridenv.2012.03.022

3. Lucini L, Pellizzoni M, Pellegrino R, Molinari GP, Colla G (2015) Phytochemical constituents and in vitro radical scavenging activity of different Aloe species. Food Chem 170:501-507. https://doi.org/10.1016/j.foodc hem.2014.08.034

4. Nejatzadeh-Barandozi F (2013) Antibacterial activities and antioxidant capacity of Aloe vera. Org Med Chem Lett 3:5. https://doi. org/10.1186/2191-2858-3-5

5. Eggersdorfer M, Wyss A (2018) Carotenoids in human nutrition and health. Arch Biochem Biophys 652:18-26. https://doi.org/10.1016/j. abb.2018.06.001

6. Moser MA, Chun OK (2016) Vitamin C and heart health: a review based on findings from epidemiologic studies. Int J Mol Sci 17:1328. https://doi. org/10.3390/ijms17081328

7. Chen H, Karne RJ, Hall G, Campia U, Panza JA, Richard O, Cannon I, Wang Y, Katz A, Levine M, Quon MJ (2006) High-dose oral vitamin C partially replenishes vitamin C levels in patients with Type 2 diabetes and low vitamin C levels but does not improve endothelial dysfunction or insulin resistance. Am J Physiol Heart Circ Physiol 290:H137-H145. https://doi. org/10.1152/ajpheart.00768.2005

8. Sandström B (2007) Micronutrient interactions: effects on absorption and bioavailability. Br J Nutr 85:S181-S185. https://doi.org/10.1049/bjn20 00312

9. Vinson JA, Al Kharrat H, Andreoli L (2005) Effect of Aloe vera preparations on the human bioavailability of vitamins $C$ and E. Phytomedicine 12:760-765. https://doi.org/10.1016/j.phymed.2003.12.013

10. Lai Q, Wang H, Guo X, Abbasi AM, Wang T, Li T, Fu X, Li J, Liu RH (2016) Comparison of phytochemical profiles, antioxidant and cellular antioxidant activities of seven cultivars of Aloe. Int J Food Sci Tech 51:14891494. https://doi.org/10.1111/ijfs. 13093

11. Upadhyay RK (2018) Nutraceutical, therapeutic, and pharmaceutical potential of Aloe vera: a review. Int J Green Pharm 12:S51

12. Jia Y, Zhao G, Jia J (2008) Preliminary evaluation: the effects of Aloe ferox Miller and Aloe arborescens Miller on wound healing. J Ethnopharmacol 120:181-189. https://doi.org/10.1016/j.jep.2008.08.008 
13. du Loots T, van der Westhuizen FH, Botes $L$ (2007) Aloe ferox leaf gel phytochemical content, antioxidant capacity, and possible health benefits. J Agric Food Chem 55:6891-6896. https://doi.org/10.1021/jf071110t

14. Singab A-NB, El-Hefnawy HM, Esmat A, Gad HA, Nazeam JA (2015) A Systemic review on Aloe arborescens pharmacological profile: biological activities and pilot clinical trials. Phytother Res. 29:1858-1867. https://doi. org/10.1002/ptr.5483

15. Wintola OA, Afolayan AJ (2011) Phytochemical constituents and antioxidant activities of the whole leaf extract of Aloe ferox Mill. Pharmacogn Mag 7:325-333. https://doi.org/10.4103/0973-1296.90414

16. Amoo SO, Aremu AO, Van Staden J (2014) Unraveling the medicinal potential of South African Aloe species. J Ethnopharmacol 153:19-41. https://doi.org/10.1016/j.jep.2014.01.036

17. Luseba D, Elgorashi EE, Ntloedibe DT, Van Staden J (2007) Antibacterial, anti-inflammatory and mutagenic effects of some medicinal plants used in South Africa for the treatment of wounds and retained placenta in livestock. S Afr J Bot 73:378-383. https://doi.org/10.1016/j.sajb.2007.03.003

18. Kumar S, Yadav A, Yadav M, Yadav JP (2017) of climate change on phytochemical diversity, total phenolic content and in vitro antioxidant activity of Aloe vera (L.) Burm.f. BMC Res Notes 10:60. https://doi.org/10.1186/ s13104-017-2385-3

19. Hazrati S, Tahmasebi-Sarvestani Z, Mokhtassi-Bidgoli A, Modarres-Sanavy SAM, Mohammadi H, Nicola S (2017) Effects of zeolite and water stress on growth, yield and chemical compositions of Aloe vera L. Agric Water Manage 181:66-72. https://doi.org/10.1016/j.agwat.2016.11.026

20. Ray A, Gupta SD, Ghosh S (2013) Evaluation of anti-oxidative activity and UV absorption potential of the extracts of Aloe vera L. gel from different growth periods of plants. Ind Crop Prod 49:712-719. https://doi. org/10.1016/j.indcrop.2013.06.008

21. Lucini L, Pellizzoni M, Molinari GP (2013) Anthraquinones and $\beta$-polysaccharides content and distribution in Aloe plants grown under different light intensities. Biochem Syst Ecol 51:264-268. https://doi. org/10.1016/j.bse.2013.09.007

22. Minjares-Fuentes R, Femenia A, Comas-Serra F, Rosselló C, RodríguezGonzález VM, González-Laredo RF, Gallegos-Infante JA, Medina-Torres L (2016) Effect of different drying procedures on physicochemical properties and flow behavior of Aloe vera (Aloe barbadensis Miller) gel. LWT 74:378-386. https://doi.org/10.1016/j.lwt.2016.07.060

23. Rajasekaran S, Ravi K, Sivagnanam K, Subramanian S (2006) Beneficial effects of aloe vera leaf gel extract on lipid profile status in rats with streptozotocin diabetes. Clin Exp Pharmacol Physiol 33:232-237. https:// doi.org/10.1111/j.1440-1681.2006.04351x

24. Debnath T, Ghosh M, Lee YM, Nath NCD, Lee K-G, Lim BO (2018) Identification of phenolic constituents and antioxidant activity of Aloe barbadensis flower extracts. Food Agric Immunol 29:27-38. https://doi. org/10.1080/09540105.2017.1358254

25. Schlatterer J, Breithaupt DE (2006) Xanthophylls in commercial egg yolks: quantification and identification by HPLC and LC-(APCI)MS using a C30 phase. J Agric Food Chem 54:2267-2273. https://doi.org/10.1021/jf053 204d

26. Giuffrida D, Pintea A, Dugo P, Torre G, Pop RM, Mondello L (2012) Determination of carotenoids and their esters in fruits of sea buckthorn (Hippophae rhamnoides L.) by HPLC-DAD-APCI-MS. Phytochem Anal 23:267-273. https://doi.org/10.1002/pca.1353

27. Folch J, Lees M, Sloane Stanley GHA (1957) Simple method for the isolation and purification of total lipides from animal tissues. J Biol Chem 226:497-509
28. Dulf FV (2012) acids in berry lipids of six sea buckthorn (Hippophae rhamnoides L., subspecies carpatica) cultivars grown in Romania. Chem Cent J 6:106. https://doi.org/10.1186/1752-153x-6-106

29. Al Majidi MIH, Al Gubury HY (2016) Determination of Vitamin C (ascorbic acid) Contents in various fruit and vegetable by UV-spectrophotometry and titration methods. 9:2972-2974

30. Huang D, Ou B, Hampsch-Woodill M, Flanagan JA, Prior RL (2002) Highthroughput assay of oxygen radical absorbance capacity (ORAC) using a multichannel liquid handling system coupled with a microplate fluorescence reader in 96-well format. J Agric Food Chem 50:4437-4444

31. Ruch RJ, Cheng SJ, Klaunig JE (1989) Prevention of cytotoxicity and inhibition of intercellular communication by antioxidant catechins isolated from Chinese green tea. Carcinogenesis 10:1003-1008. https://doi. org/10.1093/carcin/10.6.1003

32. Brand-Williams W, Cuvelier ME, Berset C (1995) Use of a free radical method to evaluate antioxidant activity. Lebensm Wiss u Technol 28:25-30

33. Rugină D, Sconța Z, Leopold L, Pintea A, Bunea A, Socaciu C (2012) Antioxidant activities of chokeberry extracts and the cytotoxic action of their anthocyanin fraction on HeLa human cervical tumor cells. J Med Food 15:700-706. https://doi.org/10.1089/jmf.2011.0246

34. Bunea C-I, Pop N, Babeş AC, Matea C, Dulf FV, Bunea A (2012) Carotenoids, total polyphenols and antioxidant activity of grapes (Vitis vinifera) cultivated in organic and conventional systems. Chem Cent J 6:66. https ://doi.org/10.1186/1752-153x-6-66

35. Ozsoy N, Candoken E, Akev N (2009) Implications for degenerative disorders: antioxidative activity, total phenols, flavonoids, ascorbic acid, beta-carotene and beta-tocopherol in Aloe vera. Oxid Med Cell Longev 2:99-106

36. Lopez-Cervantes J, Sanchez-Machado DI, Cruz-Flores P, MariscalDominguez MF, de la Mora-Lopez GS, Campas-Baypoli ON (2018) Antioxidant capacity, proximate composition, and lipid constituents of Aloe vera flowers. J Appl Res Med Aromat Plants 10:93-98. https://doi. org/10.1016/j.jarmap.2018.02.004

37. Zapata PJ, Navarro D, Guillén F, Castillo S, Martínez-Romero D, Valero D, Serrano M (2013) Characterisation of gels from different Aloe spp as antifungal treatment: Potential crops for industrial applications. Ind Crops Prod 42:223-230. https://doi.org/10.1016/j.indcrop.2012.06.002

38. Morillon V, Debeaufort F, Blond G, Capelle M, Voilley A (2002) Factors affecting the moisture permeability of lipid-based edible films: a review. Crit Rev Food Sci 42:67-89. https://doi.org/10.1080/10408690290825466

39. Vega-Gálvez A, Miranda M, Aranda M, Henriquez K, Vergara J, TabiloMunizaga G, Pérez-Won M (2011) Effect of high hydrostatic pressure on functional properties and quality characteristics of Aloe vera gel (Aloe barbadensis Miller). Food Chem 129:1060-1065. https://doi.org/10.1016/j. foodchem.2011.05.074

40. Kang M-C, Kim SY, Kim YT, Kim E-A, Lee S-H, Ko S-C, Wijesinghe WAJP, Samarakoon KW, Kim Y-S, Cho JH et al (2014) In vitro and in vivo antioxidant activities of polysaccharide purified from aloe vera (Aloe barbadensis) gel. Carbohyd Polym 99:365-371. https://doi.org/10.1016/j.carbp ol.2013.07.091

\section{Publisher's Note}

Springer Nature remains neutral with regard to jurisdictional claims in published maps and institutional affiliations. 